\title{
FERTILITY PROPERTIES AND LEAFY VEGETABLE PRODUCTION IN SOILS FERTILIZED WITH CATTLE MANURE ${ }^{1}$
}

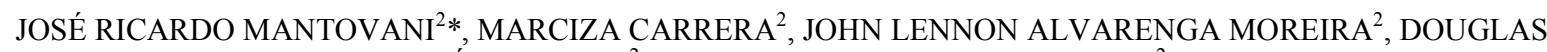 \\ JOSÉ MARQUES ${ }^{2}$, ADRIANO BORTOLOTTI DA SILVA ${ }^{2}$
}

\begin{abstract}
The effect of organic fertilization with cattle manure on fertility properties of soils with different clay contents was evaluated; as well as the influence of cattle manure fertilization on the production of lettuce, and on subsequent arugula and common chicory grown in these soils. The experiment with pot plants was arranged in randomized blocks and analyzed in a $3 \times 6$ factorial design with four replications. The treatments consisted of three soil types with different clay contents $\left(166 ; 362 ; 565 \mathrm{~g} \mathrm{~kg}^{-1}\right)$ and six cattle manure rates $\left(0 ; 10 ; 20 ; 40 ; 80\right.$, and $\left.160 \mathrm{t} \mathrm{ha}^{-1}\right)$. Batches of each soil were manured, limed, filled in pots, moistened, and incubated for 30 days. Then, mineral base fertilization was applied and one lettuce seedling per each pot was grown. After lettuce harvest, the residual effect of organic fertilization was assessed in two subsequent crops, first arugula and then common chicory. The application of up to $160 \mathrm{t} \mathrm{ha}^{-1}$ cattle manure reduces soil acidity and increases nutrient contents, particularly of $\mathrm{P}, \mathrm{K}$ and $\mathrm{Zn}$, in soils with 165 to $565 \mathrm{~g} \mathrm{~kg}^{-1}$ clay content. Fertilization with cattle manure at rates of up to $160 \mathrm{t} \mathrm{ha}^{-1}$ increases electrical conductivity of soils, without affecting growth and yield of the leafy vegetables. Cattle manuring increases the yield of lettuce, as well as of arugula and common chicory grown afterwards.
\end{abstract}

Keywords: Lactuca sativa. Cichorium intybus. Eruca sativa. Organic fertilization. Sucessive crop.

\section{ATRIBUTOS DE FERTILIDADE E PRODUÇÃO DE HORTALIÇAS FOLHOSAS EM SOLOS ADUBADOS COM ESTERCO BOVINO}

\begin{abstract}
RESUMO - O presente trabalho teve como objetivos avaliar o efeito da adubação com esterco bovino em atributos de fertilidade de solos com diferentes teores de argila e, verificar a influência da adubação com esterco bovino na produção de alface americana, e da rúcula e almeirão, cultivados de forma sucessiva a alface. O experimento foi realizado em vasos, em delineamento em blocos ao acaso, com os tratamentos arranjados em esquema fatorial 3x6 com quatro repetições. Os tratamentos foram constituídos por três solos com diferentes teores de argila $\left(166 ; 362 ; 565 \mathrm{~g} \mathrm{~kg}^{-1}\right)$ e seis doses de esterco bovino $\left(0 ; 10 ; 20 ; 40 ; 80\right.$ e $\left.160 \mathrm{t} \mathrm{ha}^{-1}\right)$. Porções de cada solo receberam esterco bovino e calcário, foram transferidas para vasos, umedecidas e incubadas por 30 dias. A seguir, efetuou-se adubação mineral de plantio e cada vaso recebeu uma muda de alface. Após a colheita da alface, para avaliar o efeito residual da adubação orgânica foram realizados dois cultivos sucessivos, um de rúcula e outro de almeirão. A aplicação de até $160 \mathrm{t} \mathrm{ha}^{-1}$ de esterco bovino diminui a acidez e, aumenta os teores de nutrientes, particularmente $\mathrm{P}, \mathrm{K}$ e $\mathrm{Zn}$ em solos com teores de argila de 165 a $565 \mathrm{~g} \mathrm{~kg}^{-1}$. A adubação com esterco bovino em doses de até $160 \mathrm{t} \mathrm{ha}^{-1}$ aumenta a condutividade elétrica dos solos, e esse acréscimo não prejudica o crescimento e a produção de hortaliças folhosas. A adubação com esterco bovino aumenta a produção de alface, como também a de rúcula e almeirão, cultivados de forma sucessiva.
\end{abstract}

Palavras-chave: Lactuca sativa. Cichorium intybus. Eruca sativa. Adubação orgânica. Cultivo sucessivo.

\footnotetext{
*Corresponding author

${ }^{1}$ Received for publication in 07/29/2015; accepted in 02/14/2017.

Paper extracted from the master's thesis of the second author.

${ }^{2}$ Agrarian Sciences Center, Universidade José do Rosário Vellano, Alfenas, MG, Brazil; mantovanijr@yahoo.com, marciza.carrera@yahoo.com.br, johnlenno3@hotmail.com, douglas.marques@unifenas.br, adriano.silva@unifenas.br.
} 


\section{INTRODUCTION}

Leafy vegetables, as well as other vegetables, are considered nutrient-demanding because they require relatively large amounts in a relatively short period of time (GRANGEIRO et al., 2006). Thus, applications of high rates of organic and mineral fertilizers are common in the cultivation of leafy vegetables (PÔRTO et al., 2008; SANTI et al., 2010).

Among the leafy vegetables, lettuce (Lactuca sativa) is the most widely cultivated and most consumed in Brazil, and the consumption and planted acreage of crisphead lettuce (Iceberg group) in particular has increased considerably in the last years (SALA; COSTA, 2012). Apart from lettuce, common chicory (Cichorium intybus) and arugula (Eruca sativa) are important leafy vegetables from the economic point of view, and have gained more space in the market (SANTOS et al., 2013; CECÍLIO FILHO et al., 2014).

Organic fertilization is frequently used by vegetable producers, and the applied rates depend, among other factors, on the type and chemical composition of the organic fertilizer and on the soil texture and initial fertility (SILVA, 2008).

Among the organic fertilizers used for vegetable cultivation, cattle manure is the most common. For the State of São Paulo, rates of 60 to $80 \mathrm{t} \mathrm{ha}^{-1}$ are recommended for lettuce, common chicory, chicory, endive, arugula, and watercress, regardless of the soil texture (TRANI; RAIJ, 1997). In the States of Santa Catarina and Rio Grande do Sul, cattle manure rates of 40 to $80 \mathrm{t} \mathrm{ha}^{-1}$ are recommended for vegetables (CQFS, 2004) and in Minas Gerais, $50 \mathrm{t} \mathrm{ha}^{-1}$ for lettuce cultivation (CFSEMG, 1999). However, there are reports of increased lettuce yields after applications of up to $150 \mathrm{t} \mathrm{ha}^{-1}$ cattle manure (PÔRTO et al., 2008).

Organic fertilizers improve the soil chemical, physical and biological properties, contributing to raise crop yields (MELO; SILVA; DIAS., 2008).
From the chemical point of view, the use of organic fertilizers such as cattle manure, maintains or increases soil organic matter contents and provides plants with nutrients (BATISTA et al., 2012). However, very high rates may disturb the balance between nutrients and increase salt contents in the soil, which can hamper vegetable yields. This problem is usually greater in sandy soils, where organic fertilizers decompose faster and salt contents in the soil solution are higher (FIOREZE et al., 2012).

In the production of leafy vegetables, crops are grown subsequently in several seasons throughout the year in the same area, usually with applications of organic fertilizer prior to the planting of each crop, without taking residual effects into account. In addition, studies that evaluate the residual effect of organic fertilization on leafy vegetable cultivation in Brazil are scarce (PEIXOTO FILHO et al., 2013).

In this context, we evaluated the effect of organic fertilization with cattle manure on fertility properties of soils with different clay contents and assessed the influence of cattle manuring on the production of crisphead lettuce as well as on the subsequent cultivation of arugula and common chicory.

\section{MATERIAL AND METHODS}

This experiment with pot plants was carried out in a greenhouse, from September 2013 to August 2014, in Alfenas, Minas Gerais. About $200 \mathrm{dm}^{3}$ of the surface layer $(0-20 \mathrm{~cm})$ of three soils with different clay contents (Table 1) were collected. After removal, each soil was separately air-dried in the shade, crumbled, sieved (4 mm mesh) and sampled for particle-size analysis (CAMARGO et al., 2009) and routine chemical analyses (SILVA, 2009) (results see Tables 1 and Table 2).

Table 1. Particle-size analysis of the soils used in the experiment.

\begin{tabular}{|c|c|c|c|c|c|c|}
\hline Soil & Coarse sand & Fine sand & Total sand & Silt & Clay & Textural class \\
\hline & & & k---g ${ }^{-1}---$ & & & \\
\hline $\mathrm{S} 1$ & 373 & 357 & 730 & 104 & 166 & Medium \\
\hline S2 & 295 & 111 & 406 & 232 & 362 & Clayey \\
\hline S3 & 237 & 90 & 327 & 108 & 565 & Clayey \\
\hline
\end{tabular}

Table 2. Chemical analyses of the soils at the start of the experiment.

\begin{tabular}{|c|c|c|c|c|c|c|c|c|c|c|c|}
\hline Soil & $\begin{array}{c}\mathrm{P} \\
\text { Mehlich } \\
\end{array}$ & O.M. & $\begin{array}{c}\mathrm{pH} \\
\mathrm{CaCl}_{2}\end{array}$ & $\mathrm{~K}$ & $\mathrm{Ca}$ & $\mathrm{Mg}$ & $\mathrm{H}+\mathrm{Al}$ & $\mathrm{Al}$ & SB & $\overline{C E C}$ & $\bar{V}$ \\
\hline & $\mathrm{mg} \mathrm{dm}^{-3}$ & $\mathrm{~g} \mathrm{dm}^{-3}$ & & 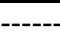 & 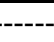 & ------ & $\mathrm{ol}_{\mathrm{c}} \mathrm{dm}^{-3}$ & & $-\cdots$ & -.---- & $\%$ \\
\hline $\mathrm{S} 1$ & 2 & 19 & 5.1 & 3.1 & 13 & 6 & 23 & 1 & 22 & 45 & 49 \\
\hline S2 & 4 & 27 & 4.6 & 3.4 & 12 & 8 & 47 & 4 & 23 & 70 & 33 \\
\hline $\mathrm{S} 3$ & 2 & 35 & 5.4 & 2.3 & 37 & 9 & 33 & 0 & 48 & 81 & 59 \\
\hline
\end{tabular}


A randomized block design was used, with treatments arranged in a $3 \times 6$ factorial design, with four replications, i.e., a total of 72 experimental units (pots). The treatments consisted of a combination of three soils (S1, S2 and S3) and six manure rates $\left(0 ; 10 ; 20 ; 40 ; 80\right.$, and $160 \mathrm{tha}^{-1)}$, based on the soil volume of each pot and the soil volume of the $0-20 \mathrm{~cm}$ layer of an area of $1 \mathrm{ha}$. The treatment without organic fertilization $\left(0 \mathrm{t} \mathrm{ha}^{-1}\right.$ manure $)$ was used as control. The tanned cattle manure used was from a dairy farm in the county of Alfenas-MG, air-dried in the shade, sieved, homogenized, and sampled to determine the chemical composition, dry basis, $\mathrm{pH}$, and moisture, as described by Tedesco et al. (1995) (Table 3).

Table 3. Chemical composition, dry basis, $\mathrm{pH}$, and moisture of cattle manure used in the experiment.

\begin{tabular}{|c|c|c|c|c|c|c|}
\hline Water content & $\mathrm{pH}$ & C-org. & $\mathrm{N}$ & $\mathrm{C} / \mathrm{N}$ ratio & $\mathrm{P}$ & $\mathrm{K}$ \\
\hline$\%$ & \multicolumn{4}{|c|}{$\mathrm{g} \mathrm{kg}^{-1}$} & \multicolumn{2}{|c|}{ - $\mathrm{g} \mathrm{kg}^{-1}$} \\
\hline 8 & 8.2 & 200.4 & 19.3 & 10 & 5.2 & 9 \\
\hline $\mathrm{Ca}$ & $\mathrm{Mg}$ & $\mathrm{S}$ & $\mathrm{B}$ & $\mathrm{Cu}$ & $\mathrm{Mn}$ & $\mathrm{Zn}$ \\
\hline ------ & ----- & --- & & $---m g ~ l$ & 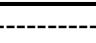 & --- \\
\hline 12.1 & 5.3 & 3.0 & 157 & 71 & 384 & 262 \\
\hline
\end{tabular}

Batches of $6.5 \mathrm{dm}^{3}$ of each soil were mixed dry with the cattle manure rates, according to the treatments, and with dolomitic limestone, to raise the initial base saturation ( $\mathrm{V} \%$ ) of each soil to $70 \%$. After mixing, the treated soils were transferred to $7-\mathrm{dm}^{3}$ pots, moistened with distilled water to about $70 \%$ of the water-holding capacity, and incubated for 30 days. During incubation, soil moisture was controlled every two days by weighing the pots and water was replaced to maintain the soil moisture content at approximately the initial water-retention level.

At the end of the incubation period, the soil batches were removed from the pots, air-dried, and $0.3 \mathrm{dm}^{3}$ soil per pot was sampled for chemical analyses of $\mathrm{pH}$ in $\mathrm{CaCl}_{2}, \mathrm{H}+\mathrm{Al}$, organic matter, $\mathrm{P}$ extracted by Mehlich, $\mathrm{K}^{+}, \mathrm{Ca}^{2+}$, and $\mathrm{Mg}^{2+}$ (SILVA, 2009), of $\mathrm{S}_{-} \mathrm{SO}_{4}{ }^{2}$, and of the micronutrients $\mathrm{Cu}, \mathrm{Fe}$, $\mathrm{Mn}$, and $\mathrm{Zn}$, and to determine the electrical conductivity, in 1:5 soil : distilled water (RAIJ et al., 2001).

After sampling, $6.2 \mathrm{dm}^{3}$ of soil were returned to the pots, remoistened to $70 \%$ of the water-holding capacity, and mineral base fertilization was applied equally in all treatments including the control, to raise the contents of most soil nutrients to medium levels. Mineral fertilization was applied, since the combined use of organic and mineral fertilizers is common in vegetable cultivation. The mineral fertilizers were applied in solution, containing $80 \mathrm{mg} \mathrm{dm}^{-3} \mathrm{P} ; 20 \mathrm{mg} \mathrm{dm}^{-3} \mathrm{~N} ; 30 \mathrm{mg} \mathrm{dm}^{-3} \mathrm{~K}$; $10 \mathrm{mg} \mathrm{dm}^{-3} \mathrm{~S} ; 2 \mathrm{mg} \mathrm{dm}^{-3} \mathrm{Zn}$, and $0.5 \mathrm{mg} \mathrm{dm}^{-3} \mathrm{~B}$, as recommended by Novais, Neves and Barros (1991) for pot experiments. An amount of 7,200 mL of solution was prepared using the reagents (PA) $\mathrm{NH}_{4} \mathrm{H}_{2} \mathrm{PO}_{4} ; \mathrm{KH}_{2} \mathrm{PO}_{4} ; \mathrm{K}_{2} \mathrm{SO}_{4} ; \mathrm{ZnSO}_{4} .7 \mathrm{H}_{2} \mathrm{O} ; \mathrm{H}_{3} \mathrm{BO}_{3}$. Of this solution, $100 \mathrm{~mL}$ per pot was applied to the soil surface in a testtube. Afterwards, one crisphead lettuce seedling, cultivar Tainá, previously grown for 27 days after sowing in polystyrene trays, was planted per pot.

At 10, 20 and 30 days after transplanting the lettuce seedlings, sidedressing was applied in all treatments, using a solution of, respectively, 20; 20 and $30 \mathrm{mg} \mathrm{dm}^{-3}$ urea N. At each sidedressing, $100 \mathrm{~mL}$ of solution per pot was applied. Lettuce was harvested on April 10, 2014, at 45 days after transplanting. The height and largest diameter of the shoot of each plant were evaluated. Afterwards, the plants were cut at the ground level, weighed to obtain the fresh matter yield of the shoot, washed, as recommended by Tedesco et al. (1995), and dried to constant weight in a forced air circulation oven, at around $65^{\circ} \mathrm{C}$.

After lettuce harvest, to evaluate the residual effect of cattle manure fertilization, arugula was cultivated and subsequently common chicory.

The arugula cultivar Cultivada was planted, and $40 \mathrm{mg} \mathrm{dm}^{-3} \mathrm{P}$ and $17 \mathrm{mg} \mathrm{dm}^{-3} \mathrm{~N}$ in form of $\mathrm{NH}_{4} \mathrm{H}_{2} \mathrm{PO}_{4}$ were applied in solution at sowing, to all treatments. The arugula seedlings were thinned to 6 plants per pot, 10 days after sowing. Ten days after thinning, sidedressing was performed in all pots by means of a solution, applying $20 \mathrm{mg} \mathrm{dm}^{-3}$ urea N. At the time of arugula harvest, 25 days after thinning, plant height and fresh and dry matter yield of the shoot were evaluated, as described for lettuce.

After arugula was harvested, fertilization was applied in all pots by means of a solution containing $40 \mathrm{mg} \mathrm{dm}^{-3} \mathrm{P}$ and $50 \mathrm{mg} \mathrm{dm}^{-3} \mathrm{~K}$, in form of $\mathrm{KH}_{2} \mathrm{PO}_{4}$. The common chicory cultivar Folha Larga was planted, and 12 days after sowing, thinned to one plant per pot. Sidedressing was carried out 10, 20 and 30 days after thinning, respectively, applying 20; 20 and $30 \mathrm{mg} \mathrm{dm}^{-3}$ urea $\mathrm{N}$ in solution to all pots. The crop was harvested 45 days after thinning, and plant height and fresh and dry matter yield of the shoot were evaluated.

The results of the soil chemical properties, of the samples collected before transplanting crisphead lettuce, and the yield of each leafy vegetable, as well as the total vegetable yield per pot (sum of lettuce, arugula and common chicory shoot yields) of the treatments were subjected to analysis of variance. The Tukey test was applied to compare the means for the qualitative factor (soils), and polynomial 
regression analysis for the quantitative factor (cattle manure rates), using the statistical program AgroEstat (BARBOSA; MALDONADO JÚNIOR, 2015).

\section{RESULTS AND DISCUSSION}

\section{Effects of cattle manure on soil fertility properties}

There was a significant interaction between the tested cattle manure rates and soil types for organic matter, $\mathrm{pH}$, potential acidity and for the contents of $\mathrm{P}, \mathrm{Zn}$ and $\mathrm{SO}_{4}{ }^{2-} \mathrm{S}$, indicating that the effect of organic fertilization on these properties depended on the soil type. Cattle manuring and soil type significantly $(\mathrm{P}<0.01)$ affected electrical conductivity (EC), and the $\mathrm{K}^{+}, \mathrm{Ca}^{2+}$ and $\mathrm{Mg}^{2+}$ contents of the soils.

On the other hand, organic fertilization did not change $(\mathrm{P}>0.05)$ the available levels of the soil micronutrients $\mathrm{Cu}, \mathrm{Mn}$ and $\mathrm{Fe}$. The $\mathrm{Cu}, \mathrm{Mn}$ and $\mathrm{Fe}$ contents of the soils did not fit to linear or quadratic regression equations either. The mean values were, respectively, 1; 9 and $62 \mathrm{mg} \mathrm{dm}^{-3}$ in the soil with

A

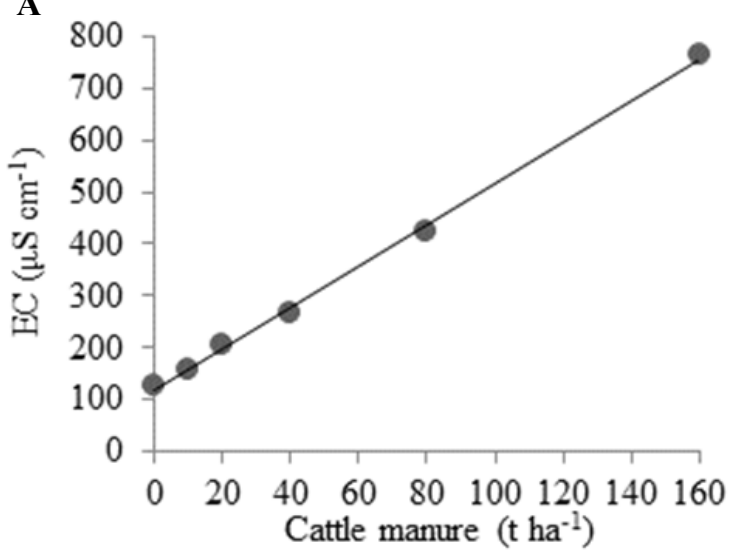

$y=3.976 x+118.960 ; R^{2}=0.998^{* *}$

C

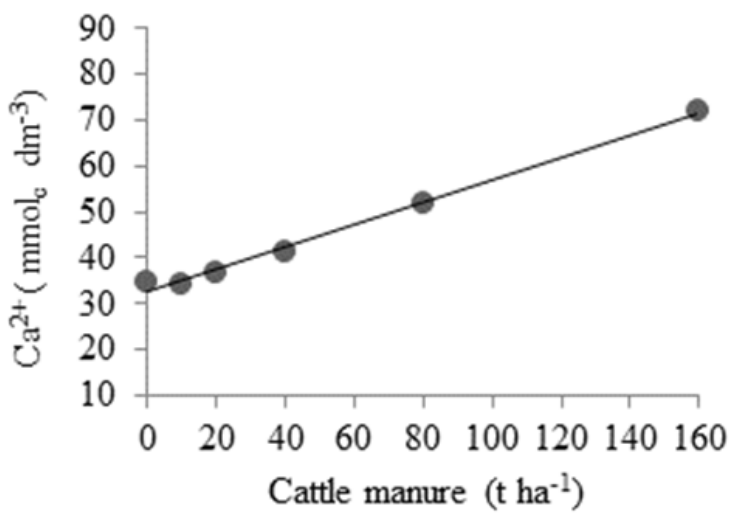

$\mathrm{y}=0.244 \mathrm{x}+32.492 ; \mathrm{R}^{2}=0.994 * *$
$166 \mathrm{~g} \mathrm{~kg}^{-1}$ clay (S1); $0.5 ; 3$ and $11 \mathrm{mg} \mathrm{dm}^{-3}$ in the soil with $362 \mathrm{~g} \mathrm{~kg}^{-1}$ clay (S2); and 5; 10 and $37 \mathrm{mg} \mathrm{dm}^{-3}$ in the soil with $565 \mathrm{~g} \mathrm{~kg}^{-1}$ clay (S3).

The chemical composition of the cattle manure applied and the rapid oxidation of $\mathrm{Fe}^{2+}$ and $\mathrm{Mn}^{2+}$ to insoluble forms in the soil can possibly explain the results obtained for the soil micronutrients $\mathrm{Cu}, \mathrm{Mn}$ and $\mathrm{Fe}$. In a 6-year observation period, Menezes and Silva (2008) found no increase either in $\mathrm{Cu}$ and $\mathrm{Fe}$ contents in sand textured soil fertilized annually with $15 \mathrm{t} \mathrm{ha}^{-1}$ manure.

The electrical conductivity and the organic matter, $\mathrm{K}^{+}$and $\mathrm{Ca}^{2+}$ contents increased linearly with cattle manure rates in the three soils (Figure 1A, B, C and D). For electrical conductivity and $\mathrm{K}^{+}$and $\mathrm{Ca}^{2+}$ contents, regardless of the soil type, the values increased, respectively, about $6.5 ; 4.0$ and 2.5 times in the treatments treated with the highest cattle manure rate in relation to the control $\left(0 \mathrm{tha}^{-1}\right.$ organic fertilizer). According to Melo, Silva and Dias (2008), the use of manure as organic fertilizer, depending on the application rates and frequency, may contribute to soil salinization, due to the electrical conductivity of these materials.

B

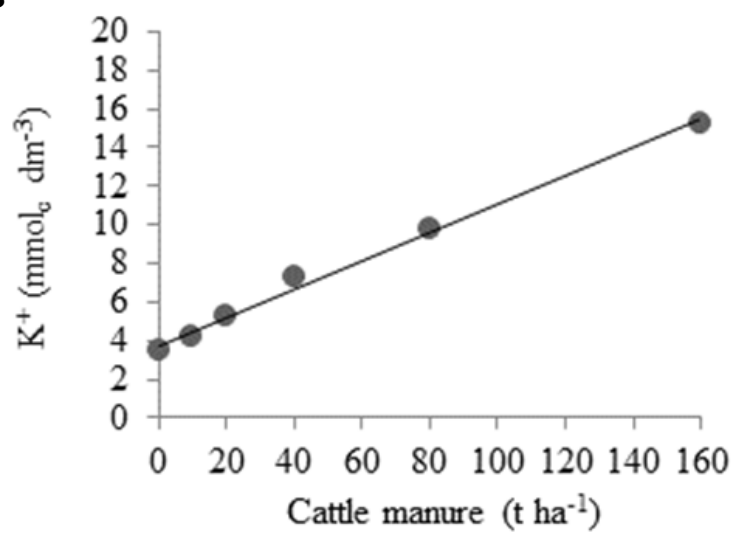

$y=0.073 x+3.756 ; R^{2}=0.994 * *$

D

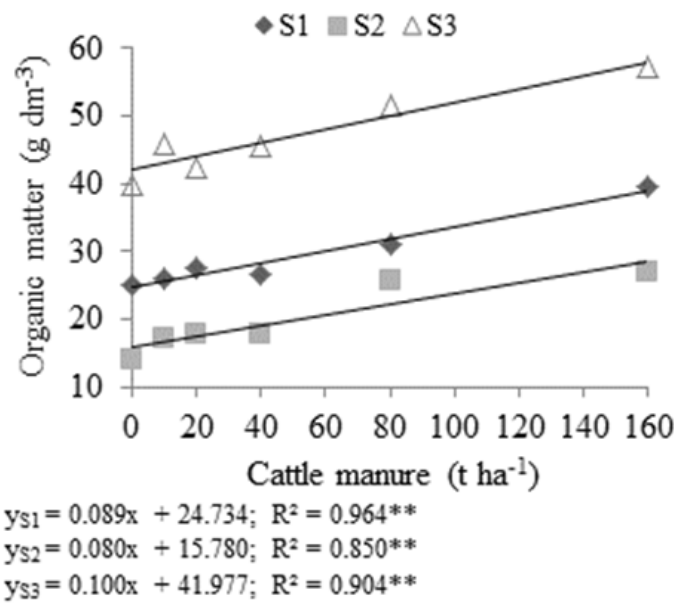

Figure 1. Effect of cattle manure fertilization on the electrical conductivity (A) and contents of $\mathrm{K}^{+}(\mathrm{B}), \mathrm{Ca}^{2+}(\mathrm{C})$ and soil organic matter (D). S1, S2 and S3 correspond to soil containing 166; 362 and $565 \mathrm{~g} \mathrm{~kg}^{-1}$ clay, respectively. 
In response to the highest rate of organic fertilizer $\left(160 \mathrm{t} \mathrm{ha}^{-1}\right)$, the increase was about 1.7 -fold in soils with lower clay content (S1 and S2) and about 1.4-fold in the soil with highest clay content (S3), in comparison with the control (Figure 1D). In laboratory studies, Yagi et al. (2003) observed an increase of $3.5 \mathrm{~g} \mathrm{dm}^{-3}$ in soil organic $\mathrm{C}$ after application of $70 \mathrm{t} \mathrm{ha}^{-1}$ cattle manure and 180 days of incubation. Menezes and Silva (2008) also reported an increase in soil organic matter after cattle manure application.

In the soils with lower clay content ( $\mathrm{S} 1$ and $\mathrm{S} 2$ ), about $53 \%$ of organic $\mathrm{C}$ added to the soil via cattle manure remained in the soil as an organic matter component, as detected by chemical analysis, while the rest was released into the atmosphere in the form of $\mathrm{CO}_{2}$. In $\mathrm{S} 3$, the amount of organic $\mathrm{C}$ added by cattle manure that remained in the soil was about $63 \%$. More clayey soils are less aerated and contain

A.

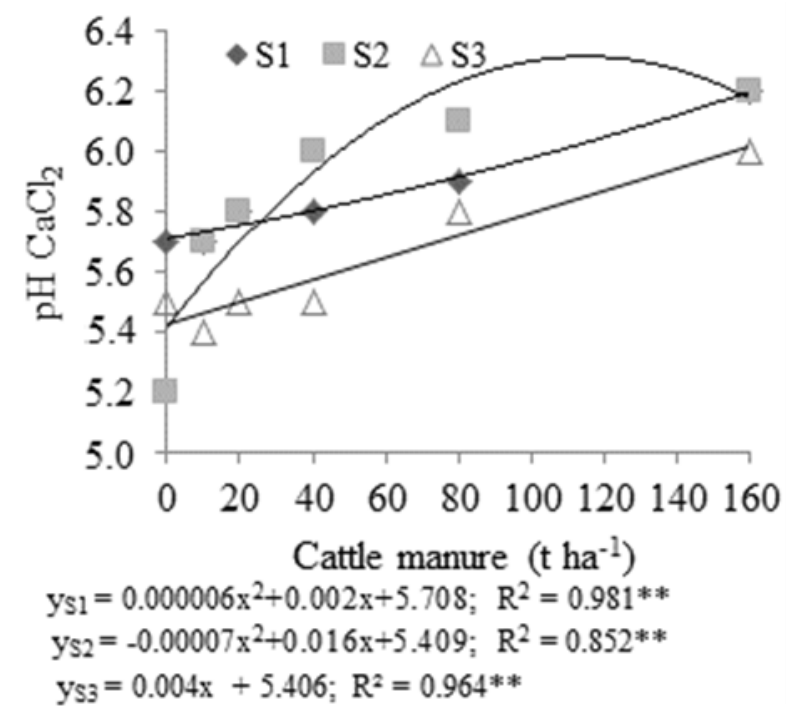

more stable aggregates, which protect organic $\mathrm{C}$ from the action of soil microorganisms. Thus, the microbial activity and organic residue decomposition are reduced in relation to soils with lower clay contents (FIOREZE et al., 2012).

Increases in organic matter contents of soils can mean improvements in soil physical and chemical properties. The main consequences of increased organic matter content for soil fertility are increased nitrogen pools for plants and higher CEC (GUIMARÃES et al., 2012).

The soils $\mathrm{S} 1$ and $\mathrm{S} 3$ responded with an increase in $\mathrm{pH}$ in $\mathrm{CaCl}_{2}$ to cattle manure fertilization (Figure 2A). In $\mathrm{S} 2$, a quadratic effect was observed and, according to the regression equation, the $\mathrm{pH}$ values increased up to an estimated organic fertilizer rate of $114 \mathrm{t} \mathrm{ha}^{-1}$. In addition, there was a linear decrease in the potential acidity $(\mathrm{H}+\mathrm{Al})$ of the soils fertilized with cattle manure rates (Figure 2B).

B.

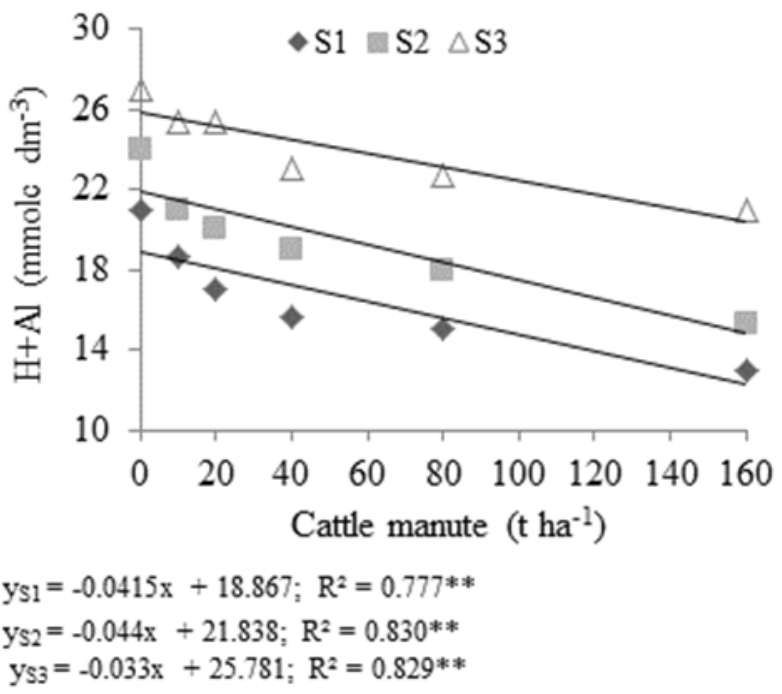

Figure 2. Effect of cattle manure fertilization on $\mathrm{pH}$ in $\mathrm{CaCl}_{2}(\mathrm{~A})$ and potential acidity (B) of the soils. $\mathrm{S} 1, \mathrm{~S} 2$ and $\mathrm{S} 3$ correspond to soils with clay contents of $166 ; 362$ and $565 \mathrm{~g} \mathrm{~kg}^{-1}$, respectively.

As shown by the results of $\mathrm{pH}$ and $\mathrm{H}+\mathrm{Al}$, cattle manure fertilization caused a decrease in soil acidity, and this effect was higher in the soils with lower clay contents (S1 and S2), due to the lower buffering capacity of these soils.

In the $\mathrm{S} 1$ and $\mathrm{S} 2$ soils, with clay contents of 166 and $362 \mathrm{~g} \mathrm{~kg}^{-1}$ respectively, the $\mathrm{pH}$ increased in the mean 0.6 units and potential acidity decreased in the mean $7 \mathrm{mmol}_{\mathrm{c}} \mathrm{dm}^{-3}$, in a comparison of the cattle manure treatment of $160 \mathrm{t} \mathrm{ha}^{-1}$ with the control. Thus, for these two soils, there was an increase of 0.1 unit in the $\mathrm{pH}$ in $\mathrm{CaCl}_{2}$ for every $30 \mathrm{t} \mathrm{ha}^{-1}$ of manure applied, apart from a reduction of about $50 \%$ in the potential acidity of the soils after application of the highest cattle manure rate. In soil S3 (565 $\mathrm{g} \mathrm{kg}^{-1}$ clay) the variations in these properties with organic fertilization were 0.4 units and $5 \mathrm{mmol}_{\mathrm{c}} \mathrm{dm}^{-3}$, respectively, corresponding to an increase of 0.1 unit in $\mathrm{pH}$ for each $40 \mathrm{t} \mathrm{ha}^{-1}$ of manure supplied to the soil, and a reduction of about $25 \%$ in potential acidity.

Similar results were obtained by Yagi et al. (2003); Guimarães et al. (2012); Braos et al. (2015) who also reported increases in soil $\mathrm{pH}$ with the application of organic fertilizers. After the application of $20 \mathrm{t} \mathrm{kg}^{-1}$ of cattle manure, Braos et al. (2015) observed an increase of 0.4 units in the $\mathrm{pH}$ in $\mathrm{CaCl}_{2}$ of the surface layer $(0-20 \mathrm{~cm})$ of a soil containing $340 \mathrm{~g} \mathrm{~kg}^{-1}$ clay. These authors attributed this result to the buffering effect of bicarbonate $\left(\mathrm{HCO}_{3}{ }^{-}\right)$and to organic anions contained in cattle manure or generated during decomposition.

According to Naramabuye and Haynes (2007), organic material contains phenolic, carboxylic and enolic groups, which can consume protons due to the association of hydrogen ions $\left(\mathrm{H}^{+}\right)$ in the soil solution with these anions, raising the soil $\mathrm{pH}$.

Rev. Caatinga, Mossoró, v. 30, n. 4, p. 825 - 836, out. - dez., 2017 
To three soils with different clay contents and CEC potential, Guimarães et al. (2012) applied up to $500 \mathrm{~m}^{3} \mathrm{ha}^{-1}$ biological sludge from the gelatine industry and found that the soils with lower buffering capacity responded with a higher $\mathrm{pH}$ increase to the organic residues.

The $\mathrm{Mg}^{2+}$ contents of the three soils were adjusted to the quadratic model as a function of cattle manure rates, and the soil contents under organic fertilization varied in the mean from 13 (high) to $16 \mathrm{mmol}_{\mathrm{c}} \mathrm{dm}^{-3}$ (very high) (Figure 3A), considering the criteria of CFSEMG (1999). In relation to the

A

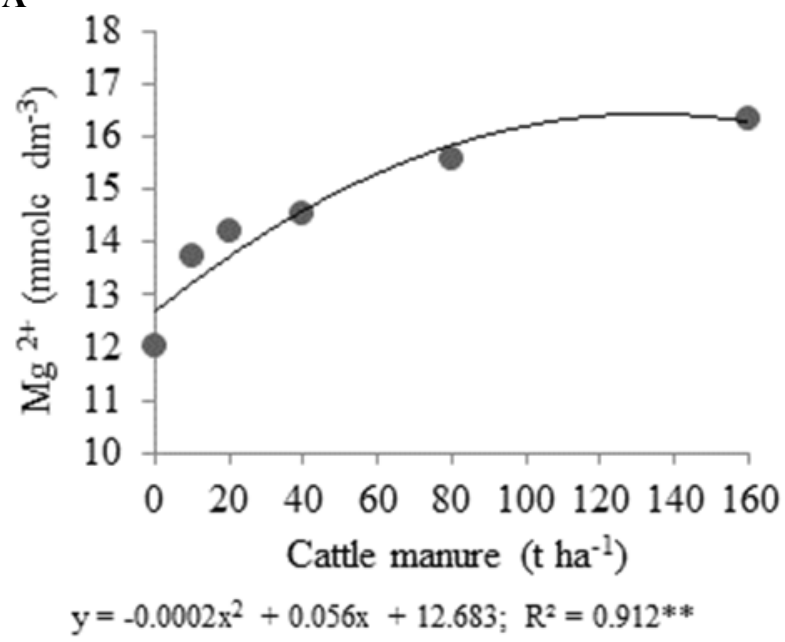

$y=-0.0002 x^{2}+0.056 x+12.683 ; R^{2}=0.912 * *$
$\mathrm{SO}_{4}{ }^{2-} \mathrm{S}$ contents, depending on the soil type, the increase with organic fertilization was higher (S3) or lower (S2) (Figure 3B). The small increase in $\mathrm{Mg}^{2+}$ contents of the soils under organic fertilization was possibly due to a low content of this nutrient in the cattle manure. In relation to the $\mathrm{SO}_{4}{ }^{2-} \mathrm{S}$ contents, the results can be explained by the differences in the initial nutrient contents between the soils, since the content was considered low in S3 and high in S2, according to the classification proposed by Raij et al. (2001).

B

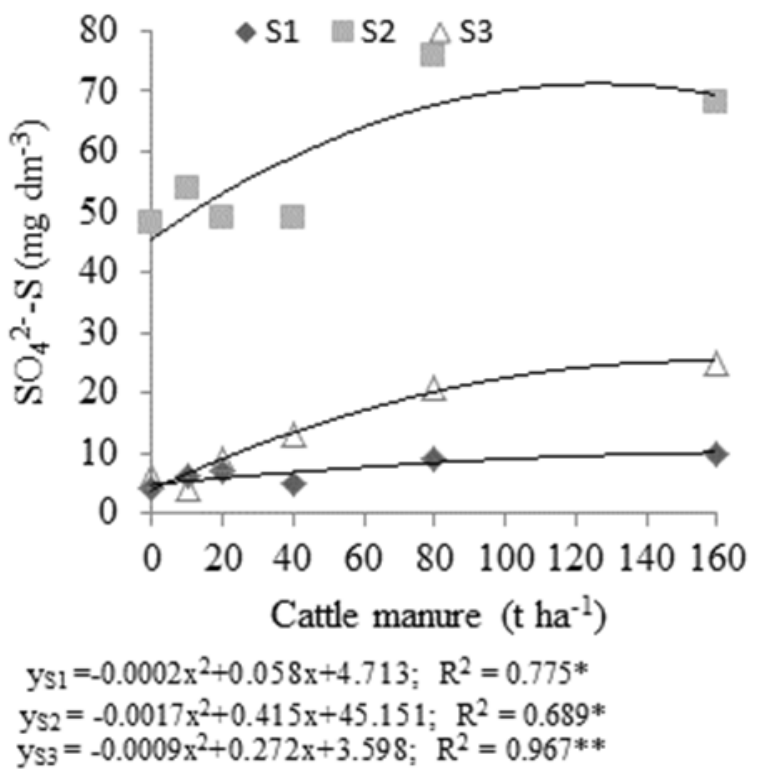

Figure 3. Effect of cattle manure fertilization on the contents of $\mathrm{Mg}^{2+}$ (A) and $\mathrm{SO}_{4}{ }^{2-} \mathrm{S}$ (B) of the soil. S1, S2 and $\mathrm{S} 3$ correspond to soils with clay contents of $166 ; 362$ and $565 \mathrm{~g} \mathrm{~kg}^{-1}$, respectively.

In relation to $\mathrm{P}$ and $\mathrm{Zn}$, the contents of the three soils increased with organic fertilization (Figures 4A and 4B). In the case of $\mathrm{P}$, the increases were more pronounced in the soil with lower clay content (S1), where the contents increased 41 times in the comparison of the control with the highest manure rate treatment. In the case of the soils S2 and S3, the increases in $\mathrm{P}$ contents were about 20 and 15-fold, respectively. This was due to the lower adsorption of the nutrient to mineral components of the solid phase, particularly $\mathrm{Fe}$ and $\mathrm{Al}$ sesquioxides, and to the greater contribution of organic and inorganic $\mathrm{P}$ forms of manure to the fraction available to the plants (P-Mehlich), in the soil with lower clay content (S1).

In areas with predominantly sandy soils treated with 12 to $20 \mathrm{t} \mathrm{ha}^{-1}$ cattle manure for a period of 15 to 40 years, Galvão, Salcedo and Oliveira (2008) observed a mean increase of 20 times the available $\mathrm{P}$ content compared with areas not treated with organic fertilizer. Braos et al. (2015) also found an increase in the levels of soil available $\mathrm{P}$ by the application of cattle manure. In the field, these authors observed that most of the $\mathrm{P}$ of cattle manure is in highly soluble inorganic and organic forms, which are rapidly transformed into the available form. According to these authors, the increase in soil available $\mathrm{P}$ by organic fertilization is due to the presence of $\mathrm{P}$ in manure, the increase in soil $\mathrm{pH}$ resulting from organic fertilization, and anion release during decomposition.

As the $\mathrm{pH}$ increases, the intensity of phosphate adsorption and precipitation processes decreases, which can lead to the extraction of higher amounts. Similarly, the release of organic anions can decrease $\mathrm{P}$ adsorption by competition or coating of the oxide surfaces and there may also be $\mathrm{Fe}$ and $\mathrm{Al}$ complexation by the simple organic compounds released from decomposition and, consequently, decrease of the phosphate precipitation reactions with these elements (SOUZA et al., 2006; BRAOS et al., 2015). 
A

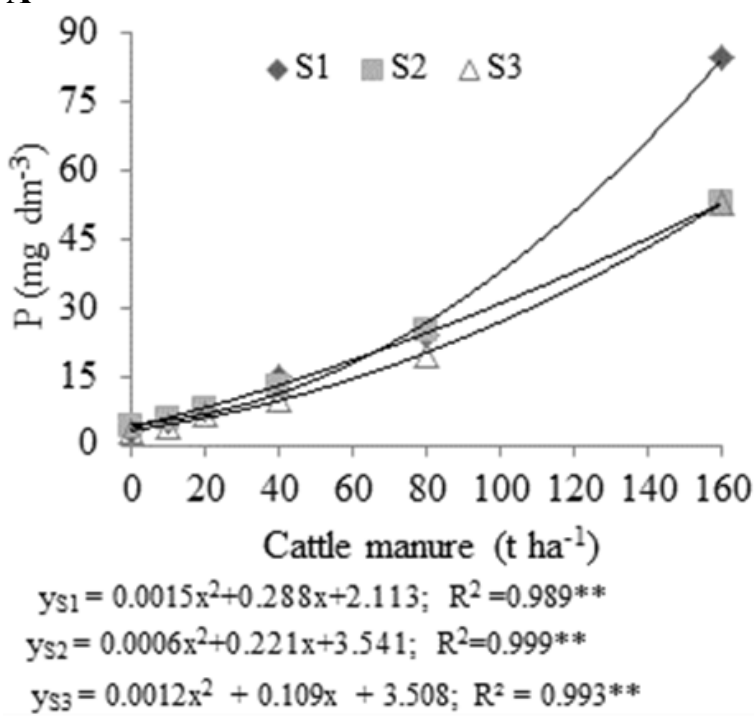

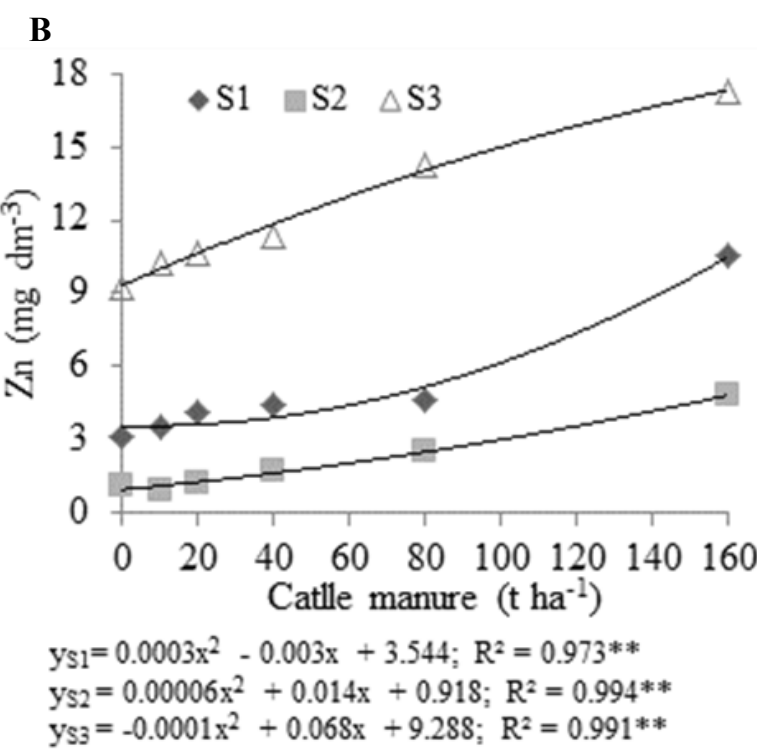

Figure 4. Effect of cattle manure fertilization on P-Mehlich (A) and Zn (B) soil contents. S1, S2 and S3 correspond to soils with clay contents of $166 ; 362$ and $565 \mathrm{~g} \mathrm{~kg}^{-1}$, respectively.

$\mathrm{Zn}$ levels in the soil showed increases of 2 to 4 times, depending on the soil used, with the application of the highest rate of cattle manure, with a lower increase in soil with higher clay content (S3). This result was probably due to the higher adsorption of the nutrient in solid phase components of the soil with higher clay content. Similar results were obtained by Menezes and Silva (2008), which verified that $\mathrm{Zn}$ levels of sandy soil doubled after annual applications of $15 \mathrm{t} \mathrm{ha}^{-1}$ of manure for six years.

Comparing the differences between soils in terms of chemical properties, the soils S1 and S3 had the highest levels of $\mathrm{K}^{+}, \mathrm{Mg}^{2+}$, Mn, and electrical conductivity than $\mathrm{S} 2$, regardless of the rate of cattle manure used (Table 4). In addition, in the soil with highest clay content (S3), the $\mathrm{Ca}^{2+}$ contents, organic matter, $\mathrm{Cu}$ and $\mathrm{Zn}$ were also higher than in the other soils.

Table 4. Fertility properties in soils with different clay contents.

\begin{tabular}{|c|c|c|c|c|c|c|c|}
\hline Soil & EC & $\mathrm{OM}$ & $\mathrm{pH}$ & $\mathrm{K}^{+}$ & $\mathrm{Ca}^{2+}$ & $\mathrm{Mg}^{2+}$ & $\mathrm{H}+\mathrm{Al}$ \\
\hline & $\mu \mathrm{S} \mathrm{cm}^{-1}$ & $\mathrm{~g} \mathrm{dm}^{-3}$ & & \multicolumn{4}{|c|}{$\mathrm{mmol}_{\mathrm{c}} \mathrm{dm}^{-3}$} \\
\hline $\mathrm{S} 1 *$ & $351 \mathrm{~A}$ & $29 \mathrm{~B}$ & $5.9 \mathrm{~A}$ & $7.8 \mathrm{~A}$ & $47 \mathrm{~B}$ & $15 \mathrm{~A}$ & $17 \mathrm{C}$ \\
\hline S2 & $269 \mathrm{~B}$ & $20 \mathrm{C}$ & $5.8 \mathrm{~A}$ & $6.3 \mathrm{~B}$ & $31 \mathrm{C}$ & $13 \mathrm{~B}$ & $20 \mathrm{~B}$ \\
\hline S3 & $353 \mathrm{~A}$ & $47 \mathrm{~A}$ & $5.6 \mathrm{~B}$ & $8.5 \mathrm{~A}$ & $56 \mathrm{~A}$ & $15 \mathrm{~A}$ & $24 \mathrm{~A}$ \\
\hline Soil & $\mathrm{SO}_{4}{ }^{2-}-\mathrm{S}$ & $\mathrm{P}$ & $\mathrm{Zn}$ & $\mathrm{Cu}$ & $\mathrm{Mn}$ & $\mathrm{Fe}$ & \\
\hline \multicolumn{8}{|c|}{ - } \\
\hline $\mathrm{S} 1 *$ & $7 \mathrm{C}$ & $23 \mathrm{~A}$ & $5.0 \mathrm{~B}$ & $1.0 \mathrm{~B}$ & $9 \mathrm{~A}$ & $62 \mathrm{~A}$ & \\
\hline S2 & $57 \mathrm{~A}$ & $18 \mathrm{~B}$ & $2.0 \mathrm{C}$ & $0.5 \mathrm{C}$ & $3 \mathrm{~B}$ & $11 \mathrm{C}$ & \\
\hline S3 & $13 \mathrm{~B}$ & $16 \mathrm{C}$ & $12.2 \mathrm{~A}$ & $5.4 \mathrm{~A}$ & $10 \mathrm{~A}$ & $37 \mathrm{~B}$ & \\
\hline
\end{tabular}

*S1, S2 and S3 correspond to soils with clay contents of 166; 362 and $565 \mathrm{~g} \mathrm{~kg}^{-1}$, respectively. OM - organic matter; EC - electrical conductivity. Means followed by the same letter in the column did not differ by the Tukey test $(\mathrm{P}<0.05)$.

It was also observed that the acidity of soil S3 was higher than that of the other soils, because the $\mathrm{pH}$ value was lower and the potential acidity higher, especially in the treatments treated with the two highest cattle manure rates. For $\mathrm{P}$, the contents were lowest in S3, in response to the three highest organic fertilizer rates. In relation to $\mathrm{SO}_{4}{ }^{2-} \mathrm{S}$, the contents were highest in soil $\mathrm{S} 2$. Aside from the clay content, the initial value of each chemical property and the $\mathrm{CEC}$ of the soils possibly explain these results.

Effect of cattle manure on leafy vegetable yields
There was a significant effect of interaction between cattle manure rates and soil types on plant height of lettuce, arugula and common chicory plants, on fresh matter and dry matter yield of lettuce, arugula and common chicory, and on the total yield of leafy vegetables, indicating that the effect of organic fertilization on these properties depended on the soil type. Organic fertilization with cattle manure did not alter $(\mathrm{P}>0.05)$ the shoot diameter of lettuce. This parameter did not fit to the regression equations either, and the mean values were $48 ; 42$ and $48 \mathrm{~cm}$ for the soils S1, S2 and S3, 
respectively.

There was a linear increase in plant height of crisphead lettuce in the soils $\mathrm{S} 1$ and $\mathrm{S} 3$, of arugula in all three soils (Figures 5A and 5B), and of common chicory only in soil S3 with cattle manure fertilization (Figure 5C). For the other soil types, it was not possible to fit an equation, observing a mean

A
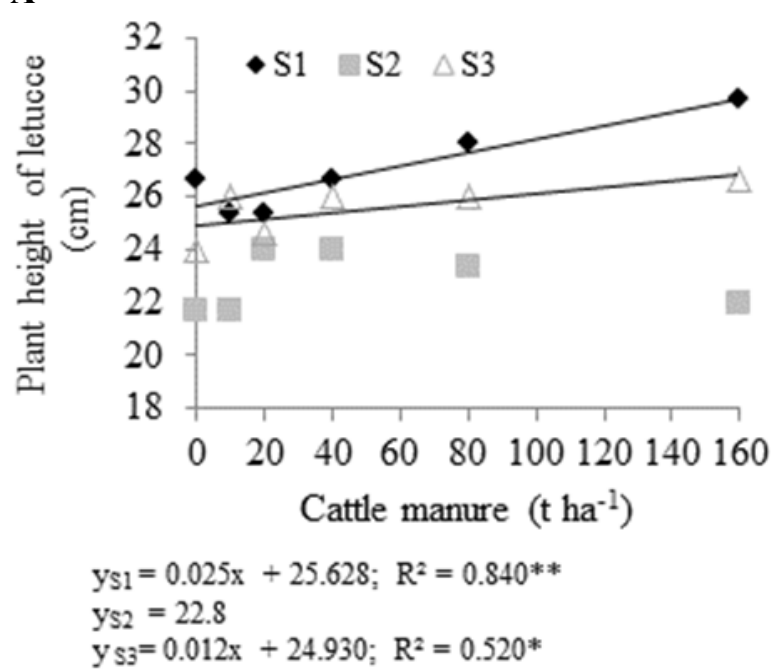

plant height of $22.8 \mathrm{~cm}$ for lettuce, 31 for arugula and $30 \mathrm{~cm}$ for common chicory. A comparison of the extreme organic fertilizer rates $\left(0\right.$ and $\left.160 \mathrm{t} \mathrm{ha}^{-1}\right)$, according to the soil type, showed plant height increases from 0 to $12 \%$ for lettuce, from 41 to $85 \%$ for arugula, and from 0 to $36 \%$ for common chicory.

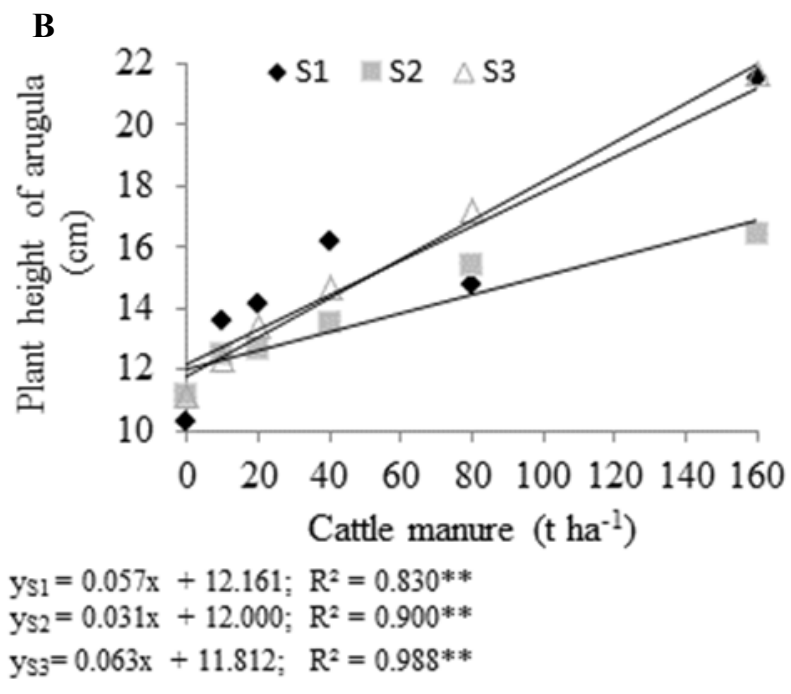

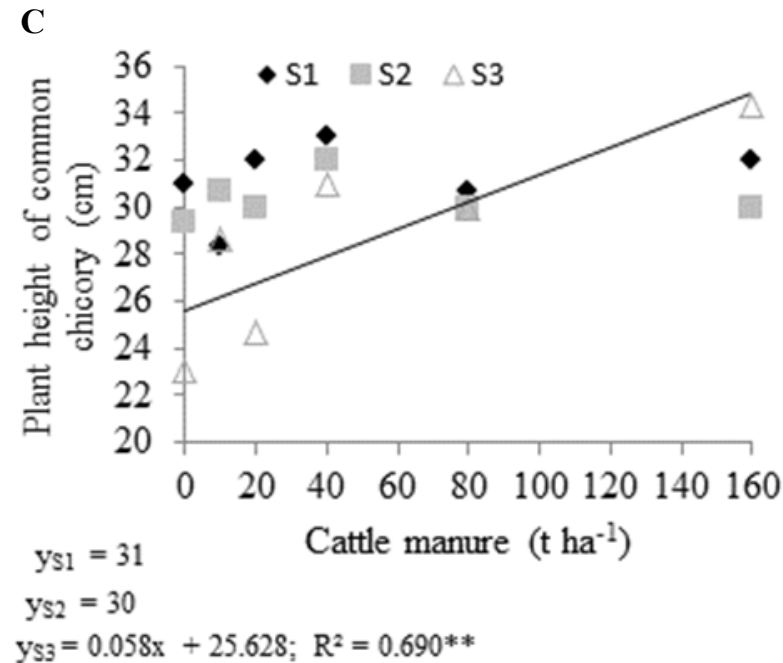

Figure 5. Effect of cattle manure fertilization on plant height of lettuce (A), arugula (B) and common chicory (C), cultivated subsequently. S1, S2 and S3 correspond to soils with contents of $166 ; 362$ and $565 \mathrm{~g} \mathrm{~kg}^{-1}$ clay, respectively.

Fresh lettuce yield increased linearly in response to cattle manure fertilization in $\mathrm{S} 1$ and $\mathrm{S} 3$ (Figure 6), and in these two soils, lettuce yield under organic fertilization ranged from 729 to $986 \mathrm{~g} \mathrm{plant}^{-1}$. In soil S2, a quadratic effect was observed, with an increase in fresh lettuce matter up to the estimated rate of $114 \mathrm{tha}^{-1}$.

The increase in fresh dry matter yield of crisphead lettuce in response to organic fertilization was 1.4 times higher in soils S1 and S3. In S2, the estimated maximum yield of fresh dry matter of lettuce at a rate of $114 \mathrm{t} \mathrm{ha}^{-1}$ would be 1.4 times that of the control.

In a field experiment with sandy textured soil,
Pôrto et al. (2008) obtained a linear increase in lettuce yield of the curly group, with the application of up to $150 \mathrm{t} \mathrm{ha}^{-1}$ cattle manure. In another study, Rodrigues et al. (2008) found that rates of $60 \mathrm{t} \mathrm{ha}^{-1}$ cattle manure increased the plant height and fresh and dry matter yields of arugula in a greenhouse pot experiment.

With regard to lettuce dry matter, a linear yield increase in response to soil manure rates was only observed in soil S3, which exceeded that of the control 1.5 times (Figure 7A). In the soils $\mathrm{S} 1$ and S2, the mean lettuce dry matter yield was 29.4 and 21.7 g plant $^{-1}$, respectively. 
A

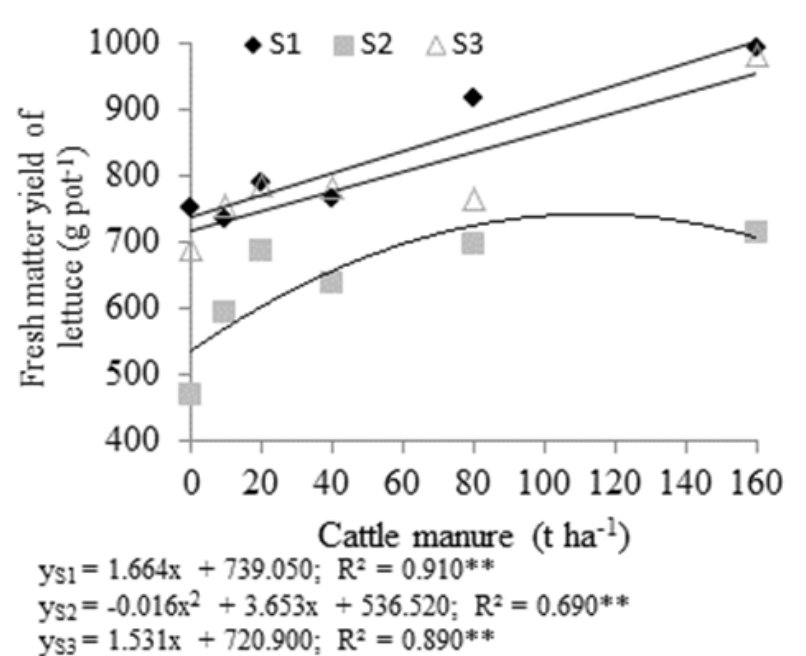

C

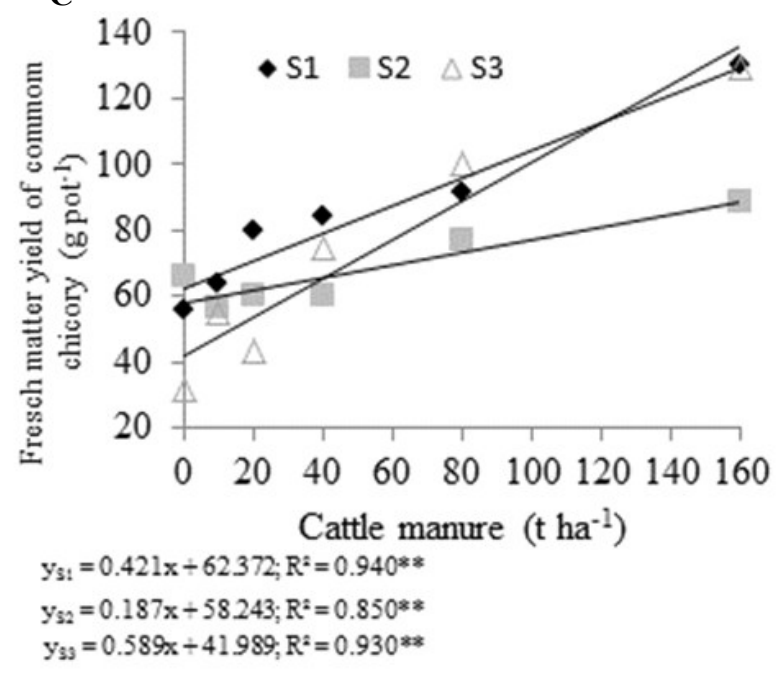

B
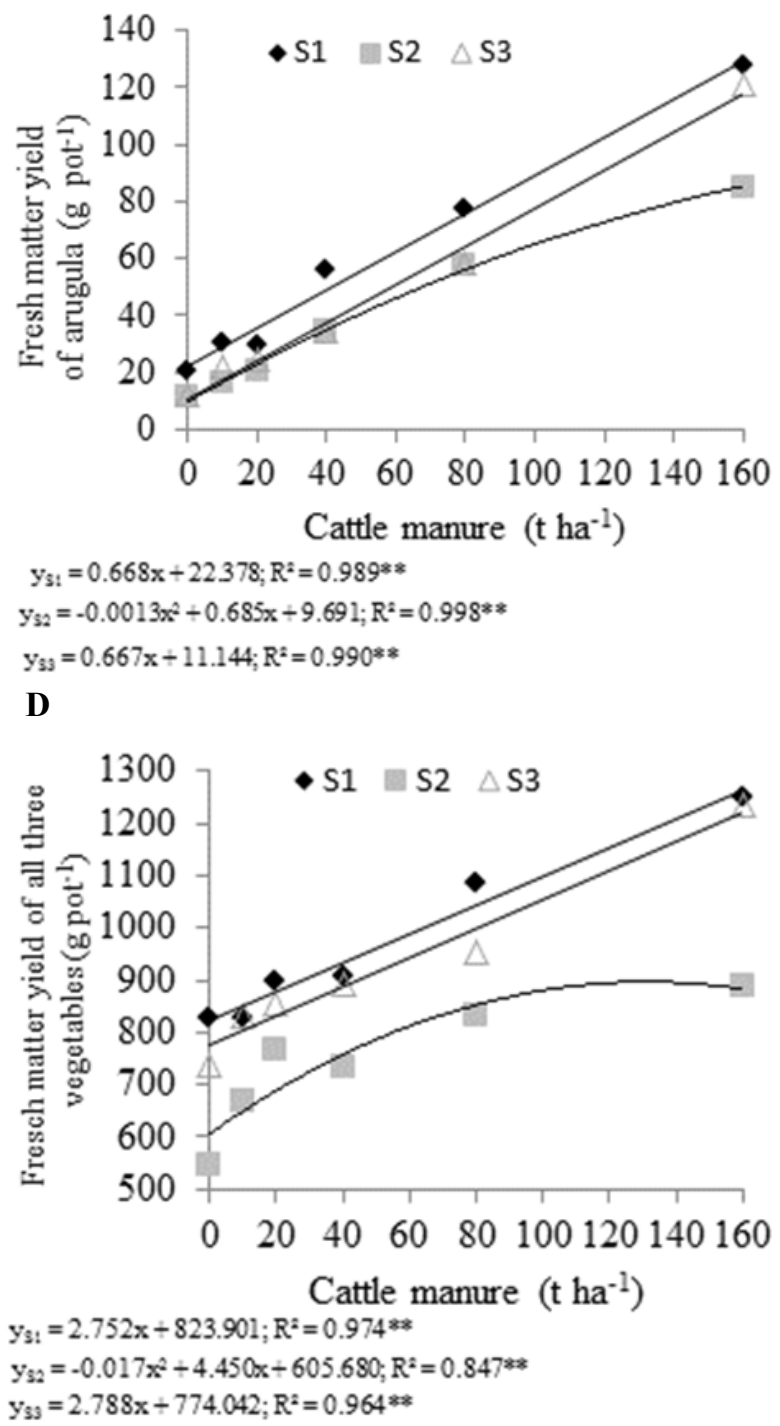

Figure 6. Effect of cattle manure fertilization on fresh matter yield of lettuce (A), arugula (B), common chicory (C) and all three vegetables (lettuce+arugula+common chicory), cultivated subsequently. S1, S2 and S3 correspond to soils with clay contents of $166 ; 362$ and $565 \mathrm{~g} \mathrm{~kg}^{-1}$, respectively.

The increase in electrical conductivity of the three soils increased to close to $800 \mu \mathrm{s} \mathrm{cm}$ in response to organic fertilization (Figure 1A), which did not affect growth and yields of crisphead lettuce or the other vegetables evaluated.

For the leafy vegetables arugula and common chicory, fresh and dry matter yields increased by cattle manure applications to the three soils (Figures 6 and 7). In the case of arugula, depending on the soil used, the application of the highest rate of cattle manure $\left(160 \mathrm{t} \mathrm{ha}^{-1}\right)$ provided 5.7 to 10.3 -fold increases in fresh matter yield, and 7 to 12 -fold increases in dry matter yield, compared to the control. For common chicory, the observed increases in fresh and dry matter yield, respectively, were 1.5 to 3.2 -fold, and 1.6 to 4 -fold.

The increases in arugula and common chicory yield in response to organic fertilization were more marked than for lettuce, indicating that the residual effect of cattle manuring on vegetable yield was higher than the effect obtained in the first cultivation after organic fertilization. This can be attributed to the slow release of $\mathrm{N}$ from cattle manure, and to the fact that the plants of the first crop exploited the soil $\mathrm{N}$ pool.

In a pot experiment with sandy soil in a greenhouse, Sampaio, Oliveira and Nascimento (2007) found that cattle manure caused immobilization of soil $\mathrm{N}$ in the first month after incorporation. After this period, $\mathrm{N}$ release increased progressively, reaching the highest amounts between three and six months after incorporation. Still, according to these authors, the effect of manure on nutrient supply for maize plants was highest in the third or fourth consecutive crop. 
A

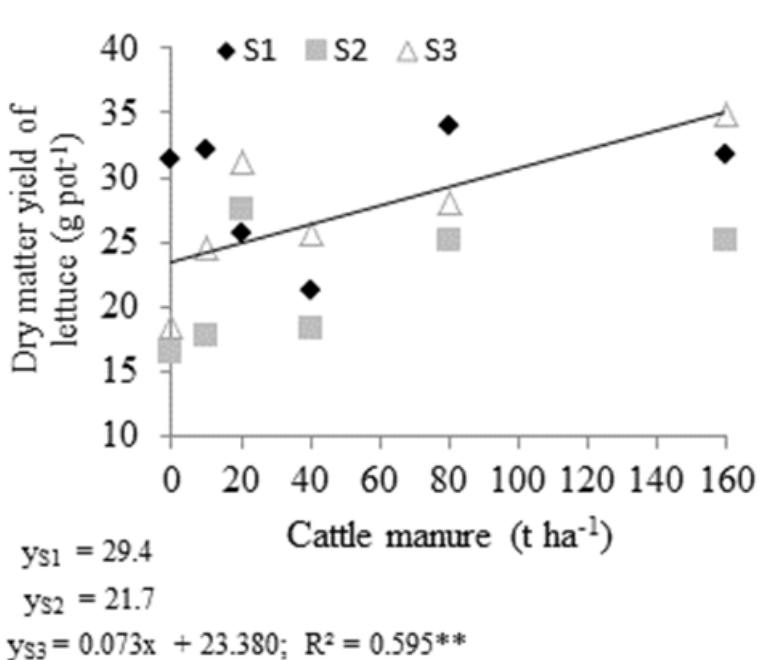

B

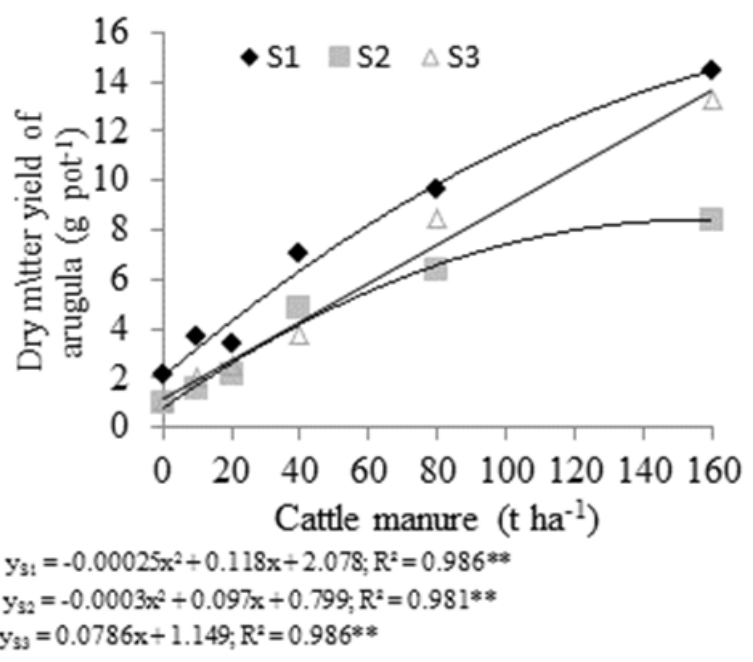

D

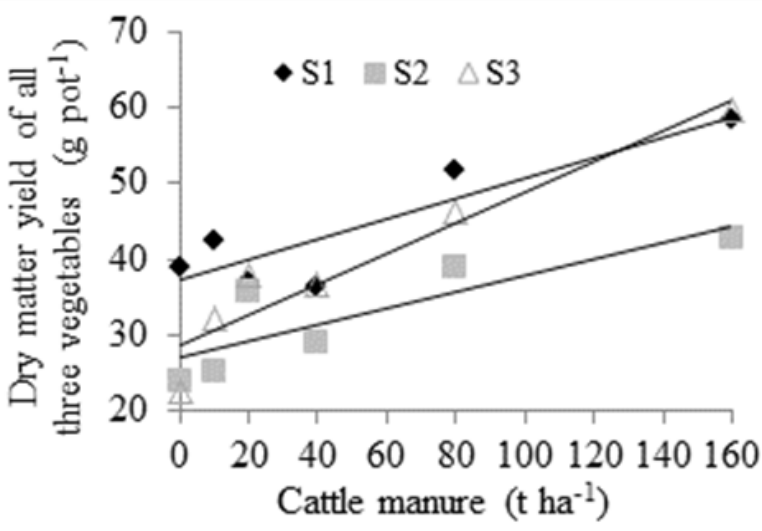

$\mathrm{y}_{\mathrm{S} 1}=0.134 \mathrm{x}+37.204 ; \mathrm{R}^{2}=0.804 * *$

$\mathrm{y}_{\mathrm{S} 2}=0.109 \mathrm{x}+26.948 ; \mathrm{R}^{2}=0.729 * *$

$\mathrm{y}_{S 3}=0.201 \mathrm{x}+28.813 ; \mathrm{R}^{2}=0.913 * *$

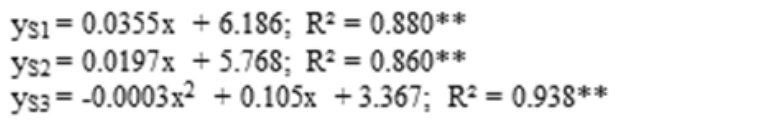

Figure 7. Effect of cattle manure fertilization on dry matter yield of lettuce (A), arugula (B), common chicory (C) and all three vegetables (lettuce+arugula+common chicory) (D), cultivated subsequently. S1, S2 and S3 correspond to soils with clay contents of $166 ; 362$ and $565 \mathrm{~g} \mathrm{~kg}^{-1}$, respectively.

In the field, Peixoto Filho et al. (2013) planted five subsequent lettuce crops, and stated an increase in the productivity of this vegetable in response to organic fertilization, as well as residual effects of animal manures, in particular of cattle manure, until the third crop. In addition, according to these authors, the mineralization of cattle manure was slower than that of chicken manure, which has a direct influence on nutrient release from organic fertilizers to plants, especially of crops with a shorter cycle, such as lettuce.

The total fresh matter yield of the vegetables (lettuce+arugula + common chicory) increased linearly with organic fertilization in soils S1 and S3. In $\mathrm{S} 2$, the effect was quadratic, with increases up to the estimated manure rate of $131 \mathrm{t} \mathrm{ha}^{-1}$ (Figure 6D). For the three soils, the total fresh matter yield of the vegetables increased about 1.5 times in relation to the control after application of the highest cattle manure rate. The improvement in soil fertility by organic fertilization possibly explains this increase in vegetable yield.

With regard to dry matter, the total yields in the three soils also increased linearly with organic fertilization and were, in the mean, 1.8 times higher in the $160 \mathrm{t} \mathrm{ha}^{-1}$ cattle manure than the control treatment (Figure 7D).

Growth and yields of the leafy vegetables were generally higher in the soil with lowest clay content (S1) than in the others (Table 5). 
Table 5. Parameters evaluated in leafy vegetables in soils with different clay contents.

\begin{tabular}{|c|c|c|c|c|c|c|}
\hline Soil & LPH & $\mathrm{APH}$ & $\mathrm{CCPH}$ & LSD & LSFM & ASFM \\
\hline & \multicolumn{4}{|c|}{ 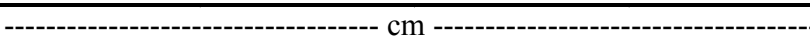 } & \multicolumn{2}{|c|}{--0--- g pot $^{-1}$} \\
\hline $\mathrm{S} 1 *$ & $26.9 \mathrm{~A}$ & $15.1 \mathrm{~A}$ & $31.2 \mathrm{~A}$ & $48 \mathrm{~A}$ & $825.1 \mathrm{~A}$ & $56.9 \mathrm{~A}$ \\
\hline $\mathrm{S} 2$ & $22.8 \mathrm{~B}$ & $13.6 \mathrm{~B}$ & $30.3 \mathrm{~A}$ & $42 \mathrm{~B}$ & $797.5 \mathrm{~A}$ & $37.6 \mathrm{C}$ \\
\hline $\mathrm{S} 3$ & $25.6 \mathrm{~A}$ & $15.1 \mathrm{~A}$ & $28.6 \mathrm{~A}$ & $48 \mathrm{~A}$ & $633.4 \mathrm{~B}$ & $45.6 \mathrm{~B}$ \\
\hline \multirow[t]{2}{*}{ Soil } & CSFM & LSDM & ASDM & CSDM & TSFM & TSDM \\
\hline & -------" & ----- & ----- g & & 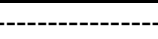 & \\
\hline $\mathrm{S} 1 *$ & $84.1 \mathrm{~A}$ & $29.4 \mathrm{~A}$ & $6.7 \mathrm{~A}$ & $8.0 \mathrm{~A}$ & $966.2 \mathrm{~A}$ & $44.2 \mathrm{~A}$ \\
\hline $\mathrm{S} 2$ & $67.9 \mathrm{~B}$ & $21.7 \mathrm{~B}$ & $4.1 \mathrm{C}$ & $6.8 \mathrm{~B}$ & $738.9 \mathrm{~B}$ & $32.6 \mathrm{C}$ \\
\hline S3 & $72.4 \mathrm{~B}$ & $27.2 \mathrm{~A}$ & $5.2 \mathrm{~B}$ & $6.8 \mathrm{~B}$ & $918.1 \mathrm{~A}$ & 39.2 B \\
\hline
\end{tabular}

*S1, S2 and S3 correspond to soils with clay contents of 166; 362 and $565 \mathrm{~g} \mathrm{~kg}^{-1}$, respectively. LPH - lettuce plant height; APH - arugula plant height; $\mathrm{CCPH}$ - common chicory plant height; LSD - lettuce shoot diameter; LSFM - lettuce shoot fresh matter; ASFM - arugula shoot fresh matter; CSFM - common chicory shoot fresh matter; LSDM - lettuce shoot dry matter; ASDM - arugula shoot dry matter; CSDM - common chicory shoot dry matter; TSFM - total shoot fresh matter of leafy vegetables (lettuce+arugula+common chicory); TSDM - total shoot dry matter of leafy vegetables (lettuce+arugula+common chicory). Means followed by the same letter in the column do not differ by the Tukey test $(\mathrm{P}<0.05)$.

The results indicated that the vegetable crops lettuce, arugula and common chicory, cultivated one after the other, respond positively to the application of high cattle manure rates in different soils, even when combined with mineral fertilization.

\section{CONCLUSIONS}

The application of up to $160 \mathrm{t} \mathrm{ha}^{-1}$ cattle manure reduces soil acidity and increases nutrient contents, particularly of $\mathrm{P}, \mathrm{K}$ and $\mathrm{Zn}$, in soils with 166 to $565 \mathrm{~g} \mathrm{~kg}^{-1}$ clay content;

Fertilization with cattle manure at rates of up to $160 \mathrm{t} \mathrm{ha}^{-1}$ increases the electrical conductivity of soils, without affecting growth and yield of leafy vegetables;

Cattle manuring increases the yield of lettuce, as well as of arugula and common chicory grown afterwards.

\section{ACKNOWLEDGEMENTS}

The authors are indebted to the Research Foundation of the State of Minas Gerais (Fapemig) and the Institutional Program of Scientific Initiation, and the Brazilian Council for Scientific and Technological Development (CNPq/Pibic) for the research fellowships for Master's degree and undergraduate students.

\section{REFERENCES}

BARBOSA, J. C.; MALDONADO JÚNIOR, W. Experimentação agronômica e AgroEstat: sistema para análises estatísticas de ensaios agronômicos. Jaboticabal, SP: Multipress, 2015. 396 p.
BATISTA, M. A. V. et al. Efeito de diferentes fontes de adubação sobre a produção de alface no município de Iguatu-CE. Revista Caatinga, Mossoró, v. 25, n. 3, p. 8-11, 2012.

BRAOS, L. B. et al. Organic phosphorus fractions in soil fertilized with cattle manure. Revista Brasileira de Ciência do Solo, Viçosa, v. 39, n. 1, p. 140-150, 2015.

CAMARgO, O. A. et al. Métodos de análise química, mineralógica e física de solos do Instituto Agronômico de Campinas. Campinas, SP: IAC, 2009. 77 p. (Boletim Técnico, 106).

CECÍLIO FILHO, A. B. et al. Épocas de cultivo e parcelamento da adubação nitrogenada para rúcula. Comunicata Scientiae, Bom Jesus, v. 5, n. 3, p. 252-258, 2014

COMISSÃO DE FERTILIDADE DO SOLO DO ESTADO DE MINAS GERAIS - CFSEMG. Recomendações para o uso de corretivos e fertilizantes em Minas Gerais. Viçosa, MG: UFV, 1999. 359 p.

COMISSÃO DE QUÍMICA E FERTILIDADE DO SOLO - RS/SC - CQFS. Manual de adubação e de calagem para os Estados do Rio Grande do Sul e de Santa Catarina. 10. ed. Porto Alegre, RS: SBCS, 2004. $400 \mathrm{p}$.

FIOREZE, C. et al. Liberação do $\mathrm{N}$ em solos de diferentes texturas com ou sem adubos orgânicos. Ciência Rural, Santa Maria, v. 42, n. 7, p. 1187-1192, 2012.

GALVÃO, S. R. S.; SALCEDO, I. H.; OLIVEIRA, F. F. Acumulação de nutrientes em solos arenosos adubados com esterco bovino. Pesquisa Agropecuária Brasileira, Brasília, v. 43, n. 1, p. 
99-105, 2008.

GRANGEIRO, L. C. et al. Acúmulo de nutrientes por três cultivares de alface cultivadas em condições do Semi-Árido. Horticultura Brasileira, Brasília, v. 24, n. 2, p. 190-194, 2006.

GUIMARÃES, R. C. M. et al. Chemical properties of soil treated with biological sludge from gelatin industry. Revista Brasileira de Ciência do Solo, Viçosa, v. 36, n. 2, p. 653-660, 2012.

MELO, L. C. A.; SILVA, C. A.; DIAS, B. O. Caracterização da matriz orgânica de resíduos de origens diversificadas. Revista Brasileira de Ciência do Solo, Viçosa, v. 32, n. 1, p. 101-110, 2008.

MENEZES, R. S. C.; SILVA, T. O. Mudanças na fertilidade de um Neossolo Regolítico após seis anos de adubação orgânica. Revista Brasileira de Engenharia Agrícola e Ambiental, Campina Grande, v. 12, n. 3, p. 251-257, 2008.

NARAMABUYE, F. X.; HAYNES, R. J. The liming effect of five organic manures when incubated with an acid soil. Journal of Plant Nutrition and Soil Science, Weinheim, v. 170, n. 5, p. 615-622, 2007.

NOVAIS, R. F.; NEVES, J. C. L.; BARROS, N. F. Ensaio em ambiente controlado. In: OLIVEIRA, A. J. et al. (Eds.) Métodos de pesquisa em fertilidade do solo. Brasília, DF: EMBRAPA-SEA, 1991. p. 189-253.

PEIXOTO FILHO, J. U. et al. Produtividade de alface com doses de esterco de frango, bovino e ovino em cultivos sucessivos. Revista Brasileira de Engenharia Agrícola e Ambiental, Campina Grande, v. 17, n. 4, p. 419-424, 2013.

PÔRTO, M. L. et al. Nitrate production and accumulation in lettuce as affected by mineral nitrogen supply and organic fertilization. Horticultura Brasileira, Brasília, v. 26, n. 2, p. 227-230, 2008.

RAIJ, B. van et al. Análise química para avaliação da fertilidade de solos tropicais. Campinas, SP: IAC, 2001. $285 \mathrm{p}$.

RODRIGUES, G. S. O. et al. Quantidade de esterco bovino no desempenho agronômico da rúcula (Eruca sativa L.), cultivar Cultivada. Revista Caatinga, Mossoró, v. 21, n. 1, p. 162-168, 2008.

SALA, F. C.; COSTA, C. P. Retrospectiva e tendência da alfacicultura brasileira. Horticultura Brasileira, Brasília, v. 30, n. 2, p. 187-194, 2012.
SAMPAIO, E. V. S. B; OLIVEIRA, N. M. B.; NASCIMENTO, P. R. F. Eficiência da adubação orgânica com esterco bovino e com Egeria densa. Revista Brasileira de Ciência do Solo, Viçosa, v. 31, n. 5, p. 995-1002, 2007.

SANTI, A. et al. Ação de material orgânico sobre a produção e características comerciais de cultivares de alface. Horticultura Brasileira, Brasília, v. 28, n. 1, p. 87-90, 2010.

SANTOS, F. et al. Desempenho agronômico de quatro cultivares de almeirão. Horticultura Brasileira, Brasília, v. 31, n. 1, p. 153-156, 2013.

SILVA, C. A. Uso de resíduos orgânicos na agricultura. In: SANTOS, G. A. et al. (Eds.) Fudamentos da matéria orgânica do solo: ecossistemas tropicais e subtropicais. 2. ed. Porto Alegre, RS: Metropole, 2008. cap. 32, p. 597-624.

SILVA, F. C. Manual de análises químicas de solos, plantas e fertilizantes. 2. ed. Brasília, DF: EMBRAPA, 2009. 627 p.

SOUZA, R. F. et al. Calagem e adubação orgânica: influência na adsorção de fósforo em solos. Revista Brasileira de Ciência do Solo, Viçosa, v. 30, n. 6, p. 975-983, 2006

TEDESCO, M. J. et al. Análise de solo, plantas e outros materiais. 2. ed. Porto Alegre, RS: UFRGS, 1995. $147 \mathrm{p}$

TRANI, P.E.; RAIJ, B. van. Hortaliças. In: RAIJ, B. van et al. (Eds.). Recomendações de adubação e calagem para o Estado de São Paulo. 2. ed. Campinas, SP: IAC, 1997. p. 157-164. (Boletim Técnico, 100).

YAGI, R. et al. Organic matter fractions and soil fertility under the influence of liming, vermicompost and cattle manure. Scientia Agricola, Piracicaba, v. 60, n. 3, p. $549-557,2003$ 